\title{
Isolated dentinogenesis imperfecta and in association with osteogenesis imperfecta - a literature review
}

\author{
Andrei Kozma', Doriana Agop Forna², Viorica Radoi ${ }^{3 *}$, Ana Maria Alexandra Stanescu ${ }^{3}$, \\ Radu Ursu ${ }^{3}$, Laurentiu Camil Bohaltea ${ }^{3}$ \\ ${ }^{1}$ Research Department in Social Pediatrics and Obstetrics, \\ "Alessandrescu-Russescu" National Institute for Mother and Child Health, Bucharest, Romania \\ 2"Grigore T. Popa" University of Medicine and Pharmacy, Iasi, Romania \\ 3"Carol Davila" University of Medicine and Pharmacy, Bucharest, Romania
}

\begin{abstract}
Dental development is part of the craniofacial organogenesis, starting from the pluripotent cephalic neural crest cells, continuing with their movement towards the first pharyngeal arch and leading to the development of many elements of the craniofacial structures. Tooth developmental disorders can be caused by genetic abnormalities at any level of the genomic information (chromosomal, monogenic, polygenic-multifactorial). Dentin genetic abnormalities have been known for several years and include two entities: dentinogenesis imperfecta (DI) and dentin dysplasia (DD). Osteogenesis imperfecta (OI) (also known as brittle bone disease) is a connective tissue disorder (collagen disorders) characterized by bone fragility leading to recurrent bone fractures and in the severe forms to bone deformities and shortening. 12 clearly described types of OI and 2 other OI phenotypical entities have been described until present, the best known being due to various COL1A1 and COL1A2 mutations, (genes which encode for the collagen type I pro-alpha 1 and 2 polypeptide chains). Although DI is part of the clinical features reported in OI, not all types of Ol have dentin genetic anomalies.For patients with $\mathrm{OI}$, it is extremely important that the clinician understands the possible dental implications associated with the disease. Children with OI should be examined as soon as teeth are erupted to prevent loss of tooth structure and seen frequently to restore any new enamel fracture and maintain their oral health. Genetic testing is available in single-gene or multigene panel analysis and is essential in the diagnosis and in defining the type of OI or DI of each patient.
\end{abstract}

Keywords: dentinogenesis, osteogenesis, gene panel

It is a well-known fact the numerous genetic factors are involved in tooth morphogenesis, with a continuously rising number of associated candidate genes and variants.

Dental development is part of the craniofacial organogenesis, starting from the pluripotent cephalic neural crest cells, continuing with their movement towards the first pharyngeal arch and leading to the development of many elements of the craniofacial structures (1-3).

Tooth developmental disorders can be caused by genetic abnormalities (at any level of the genomic information (chromosomal, monogenic, polygen- ic-multifactorial) $(3,4)$. They have been reported either as isolated defects or part of the symptomatology of various complex multisystemic genetic syndromes (4).

Numerous classifications have been made in respect of dental anomalies, depending on tooth shape, number, size, structure, formation, a.o. $(5,7)$.

Certain genetic and biological defects as are the embryonic origins of dental cells, dentition patterns, morpho- and histogenesis, the specific location of tooth development, tooth identity, final differentiation of odontoblasts and ameloblasts, synthesis and mineralization of the dentine and 
enamel matrix, development of the root and periodontium, eruption of teeth are linked to these classifications (6-9).

Dental anomalies and defects are a consequence of mistakes during any of these complex processes.

The involvement of the environment in gene functioning is well documented and represent, along with the human genome, and essential factor in defining certain acquired dental anomalies $(2,10,11)$.

Important progress has been made during regarding biological pathways associated with dentin matrix formation and tooth disease $(12,13)$.

Dentin genetic abnormalities have been known for several years and include two entities: dentinogenesis imperfecta (DI) and dentin dysplasia (DD) $(2,4)$. The estimated incidence of DI is between $1 / 6,000$ and $1 / 8,000$ and approx. $1 / 100000$ for dentin dysplasia (1).

Dentinogenesis imperfecta is an autosomal dominant disease characterized by severe hypo- mineralization of dentin and altered dentin structure and has been classified into three types (11).

Shields type I DI is associated with osteogenesis imperfecta that affects the connective tissues resulting in dentin dysplasia and is caused by mutations in the COL1A1 gene (collagen, type 1, Alpha-1) located on chromosome $17 \mathrm{q}$ and COL1A2 gene on chromosome $7 \mathrm{q}(11,14)$.

Shields type II DI (OMIM 125490) is caused by pathogenic mutations in the DSPP gene (dentin sialophosphoprotein, OMIM 125485), located at 4q22.1. It is identical clinically, radiologically, and histologically to type 1 , but without being associated to osteogenesis imperfecta $(1,14,15)$.

Shields type III DI (OMIM 125500) is a rare form of DI involving, unlike types 1 and 2, teeth with shell-like appearance and multiple pulp exposures. Mutations in the DSPP gene have also been reported to be causative for this DI type $(1,14)$.

Osteogenesis imperfecta (OI) (also known as brittle bone disease) is a connective tissue disorder

TABLE 1. Types of osteogenesis imperfecta with /without dentinogenesis imperfecta

\begin{tabular}{|c|c|c|c|c|c|c|c|}
\hline Type of 01 & $\begin{array}{l}\text { Inheritance } \\
\text { pattern }\end{array}$ & $\begin{array}{l}\text { Disease } \\
\text { OMIM } \\
\text { No. }\end{array}$ & Severity & $\begin{array}{l}\text { With / without } \\
\text { DI }\end{array}$ & $\begin{array}{l}\text { Causative } \\
\text { gene }\end{array}$ & $\begin{array}{l}\text { OMIM } \\
\text { No. }\end{array}$ & Location \\
\hline 1 & $A D$ & 166200 & Mild & Dl - rare & COL1A1 & 120150 & $17 q 21.33$ \\
\hline II & $A D$ & 166210 & Lethal & No DI & $\begin{array}{l}\text { COL1A1 } \\
\text { COL1A2 }\end{array}$ & $\begin{array}{l}120150 \\
120160\end{array}$ & $\begin{array}{c}17 q 21.33 \\
7 q 21.3\end{array}$ \\
\hline III & $A D$ & 259420 & $\begin{array}{c}\text { Severe } \\
\text { (deforming) }\end{array}$ & $\begin{array}{c}\text { DI - both primary } \\
\text { and secondary } \\
\text { teeth }\end{array}$ & $\begin{array}{l}\text { COL1A1 } \\
\text { COL1A2 }\end{array}$ & 120160 & $7 q 21.3$ \\
\hline IV & $A D$ & 166220 & Moderate & DI present & $\begin{array}{l}\text { COL1A1 } \\
\text { COL1A2 }\end{array}$ & 120160 & $7 q 21.3$ \\
\hline V & $A D$ & 610967 & $\begin{array}{l}\text { Highly variable (even } \\
\text { among carriers of the } \\
\text { same muta on) }\end{array}$ & $\mathrm{DI}$ - rare & IFITM5 & 614757 & $11 \mathrm{p} 15.5$ \\
\hline VI & $A R$ & 613982 & $\begin{array}{c}\text { Severe } \\
\text { ('fish scale' lamellae at } \\
\text { iliac biopsy) }\end{array}$ & No DI & SERPINF1 & 172860 & $17 p 13.3$ \\
\hline VII & $A R$ & 610682 & Extremely severe - lethal & No DI & CRTAP & 605497 & $3 p 22.3$ \\
\hline VIII & AR & 610915 & Severe - lethal (no DI) & NoDI & $\begin{array}{c}\text { P3H1 } \\
\text { (LEPRE1) }\end{array}$ & 610339 & 1p34.2 \\
\hline IX & AR & 259440 & Moderate-severe & No DI & PPIB & 123841 & $15 q 22.31$ \\
\hline$x$ & AR & 613848 & Severe & $\begin{array}{l}\text { Dl reported in } \\
\text { some pa ents }\end{array}$ & SERPINH1 & 600943 & $11 q 13.5$ \\
\hline $\begin{array}{c}\mathrm{XI} / \\
\text { BRKS1 }\end{array}$ & AR & 610968 & $\begin{array}{c}\text { Moderate - severe (also } \\
\text { Bruck syndrome 1) }\end{array}$ & $\begin{array}{l}\text { Dl reported in } \\
\text { some pa ents }\end{array}$ & FKBP10 & 607063 & $17 q 21.2$ \\
\hline XII & $A R$ & 613849 & Moderate-severe & No DI & SP7 & 606633 & $12 q 13.13$ \\
\hline BRKS2 & $A R$ & 609220 & $\begin{array}{c}\text { Moderate - severe Bruck } \\
\text { syndrome } 2\end{array}$ & No reports on DI & PLOD2 & 601865 & $3 q 24$ \\
\hline OPPG & $A R$ & 259770 & $\begin{array}{l}\text { Ocular Ol (osteoporosis } \\
\text { pseudoglioma } \\
\text { syndrome) }\end{array}$ & No reports on DI & LRP5 & 603506 & $11 q 13.2$ \\
\hline
\end{tabular}


(collagen disorders) characterized by bone fragility leading to recurrent bone fractures and in the severe forms to bone deformities and shortening (15-18). The incidence of OI is 6-20/100,000 newborns, with a 4-10 / 100,000 prevalence rate $(2,3)$.

12 clearly described types of OI and 2 other OI phenotypical entities have been described until present, the best known being due to various COL1A1 and COL1A2 mutations, (genes which encode for the collagen type I pro-alpha 1 and 2 polypeptide chains) (Table 1) $(14,19,20)$.

Although DI is part of the clinical features reported in OI, not all types of OI have dentin genetic anomalies (Table 1) $(4,14,21)$.

\section{DIAGNOSIS}

Because of the numerous and severe skeletal and dental abnormalities occurring with OI, dental treatment is challenging for both patient and dentist. Being informed about the complexity of the dental treatment for these children will help the dentist in the management of each specific case $(5,8,21,22)$.

The diagnosis of dentinogenesis imperfecta is set through clinical examination that is consistent with the signs of the phenotype. A dental X-ray is

important in diagnosing dentinogenesis imperfecta. The specific signs found in a clinical exam may differ depending on the type of dentinogenesis imperfecta $(1,6,22)$.

\section{CONCLUSIONS}

Odontogenesis imperfecta is a genetic collagen disorder with dentinogenesis imperfecta as its dental counterpart.

For patients with OI, it is extremely important that the clinician understands the possible dental implications associated with the disease. Children with OI should be examined as soon as teeth are erupted to prevent loss of tooth structure and seen frequently to restore any new enamel fracture and maintain their oral health.

Genetic testing is available in single-gene or multigene panel analysis and is essential in the diagnosis and in defining the type of odontogenesis imperfecta or dentinogenesis imperfecta of each patient.

\section{Acknowledgement}

All authors have same contribution for this article.

Conflict of interest: none declared Financial support: none declared

\section{REFERENCES}

1. Witkop CJ Jr. Hereditary defects of dentin. Dent Clin North Am. 1975; 19:25-45.

2. McKnight DA, Simmer JP, Hart PS, Hart TC, Fisher LW. Overlapping DSPP mutations cause dentin dysplasia and dentinogenesis imperfecta. J Dent Res 2008; 87: 1108-1111.

3. MacDougall M, Dong J, Acevedo AC. Molecular basis of human dentin diseases. Am J Med Genet, 2006; 140: 2536-2546.

4. Linde A, Goldberg M. Dentinogenesis. Crit Rev Oral Biol Med 1993; 4: 679-728. Ruch JV, Lesot H, Begue-Kirn C: Odontoblast differentiation. Int J Dev Biol 1995; 39: 51-68.

5. Butler WT, Brunn JC, Qin C, McKee MD. Extracellular matrix proteins and the dynamics of dentin formation. Connect Tissue Res 2002; 43: 301-307.

6. Keyvan Moharamzadeh. Dentinogenesis Imperfecta and Dentine Dysplasia, Diseases and Conditions in Dentistry, (99-104), (2018).

7. Ghassem Ansari, Mojtaba Vahid Golpayegani, Richard Welbury. Bibliography, Atlas of Pediatric Oral and Dental Developmental Anomalies, (109-113), (2018).

8. F Li, Y Liu, H Liu, J Yang, F Zhang, H Feng. Phenotype and genotype analyses in seven families with dentinogenesis imperfecta or dentin dysplasia, Oral Diseases, 23, 3, (360-366), (2017).

9. Witkop CJ, Rao S. Inherited Defects in Tooth Structure. Baltimore: Williams and Wilkins; 1971. p. 153.

10. Boughman JA, Halloran SL, Roulston D, Schwartz S, Suzuki JB, Weitkamp LR et al. An autosomal-dominant form of juvenile periodontitis: Its localization to chromosome 4 and linkage to dentinogenesis imperfecta and Gc. J Craniofac Genet Dev Biol. 1986;6:341-50.

11. Shields ED, Bixler D, El-Kafrawy AM. A proposed classification for heritable human dentin defects with a description of a new entity. Arch Oral Biol. 1973;18:543-53.
12. Witkop CJ Jr. Amelogenesis imperfecta, dentinogenesis imperfecta and dentin dysplasia revisited: Problems in classification. J Oral Pathol. 1988;17:547-53.

13. www.omim.org

14. Devaraju D, Devi BY, Vasudevan V, Manjunath V. Dentinogenesis imperfecta type I: A case report with literature review on nomenclature system. J Oral Maxillofac Pathol. 2014;18:S131.

15. Pintor A, Alexandria A, Marques A, Abrahao A, Guedes F, Primo L. Primary Teeth: A Case Report. Ultrastruct Pathol. 2015;39:281-5.

16. Akhlaghi N, Eshghi AR, Mohamadpour M. Dental Management of a Child with Dentinogenesis Imperfecta: A Case Report. J Dent. 2016;13:133

17. Xiao S, Yu C, Chou X et al. Dentinogenesis imperfecta 1 with or without progressive hearing loss is associated with distinct mutations in DSPP. Nat Genet 2001; 27: 201-204.

18. Sillence DO, Senn A, Danks DM. Genetic heterogeneity in osteogenesis imperfect. J Med Genet. 1979;16:101-6.

19. Glorieux FH, Rauch F, Plotkin H, Wart L, Travers R, Roughley P et al. Type $V$ osteogenesis imperfecta: a new form of brittle bone disease. $J$ Bone Miner Res. 2000;15:1650-8.

20. Huber MA. Osteogenesis imperfecta. Oral Surg Oral Med Oral Pathol Oral Radiol Endod. 2007;103:314-20.

21. O'Connel AC, Marini JC. Evaluation of oral problems in an osteonesis imperfect population. Oral Surg Oral Med Oral Pathol Oral Radiol Endod. 1999;87:189-96.

22. Teixeira CS, Felippe MC, Felippe TF, Silva-Sousa YT, Sousa-Neto $M D$. The role of dentists in diagnosing osteogenesis imperfecta in patients with dentinogenesis imperfecta. J Am Dent Assoc. 2008:139:906-14. Histological and Ultrastructure Analysis of Dentin Dysplasia Type I in 